\title{
Count on Confidence
}


Titles in the Macmillan Modern Office Series

Elementary Exercises in Word Processing

- Student's Book, Teacher's Book

Brown \& Tiffney

English Language Skills

Hughes

Integrated Assignments in Secretarial, Office and Business Procedures Pack

McFetridge

Quickly into QWERTY

Hughes

Starting in the Office Pack

Barnes

Easily into ...

dBase III Plus

Gosling

dBase III Plus Programming

Gosling

(Exercise disks available)

DisplayWrite 4

Gosling

Displaywrite 4 Advanced Features

Gosling

DOS

Gosling

(Exercise disks available)

LocoScript for the Amstrad PCW

Rogers

Lotus 1-2-3

Gilligan

MultiMate Advantage II

Gosling

MultiMate Advantage II Advanced Features

Gosling

SuperCalc 4

Gosling

SuperCalc 4 Advanced Features

Gosling

(Exercise disks available)

WordPerfect 5

Gosling

WordStar

Simons

WordStar 1512

Gosling

WordStar 2000

Simons

WordStar 2000 Advanced Features

Simons 


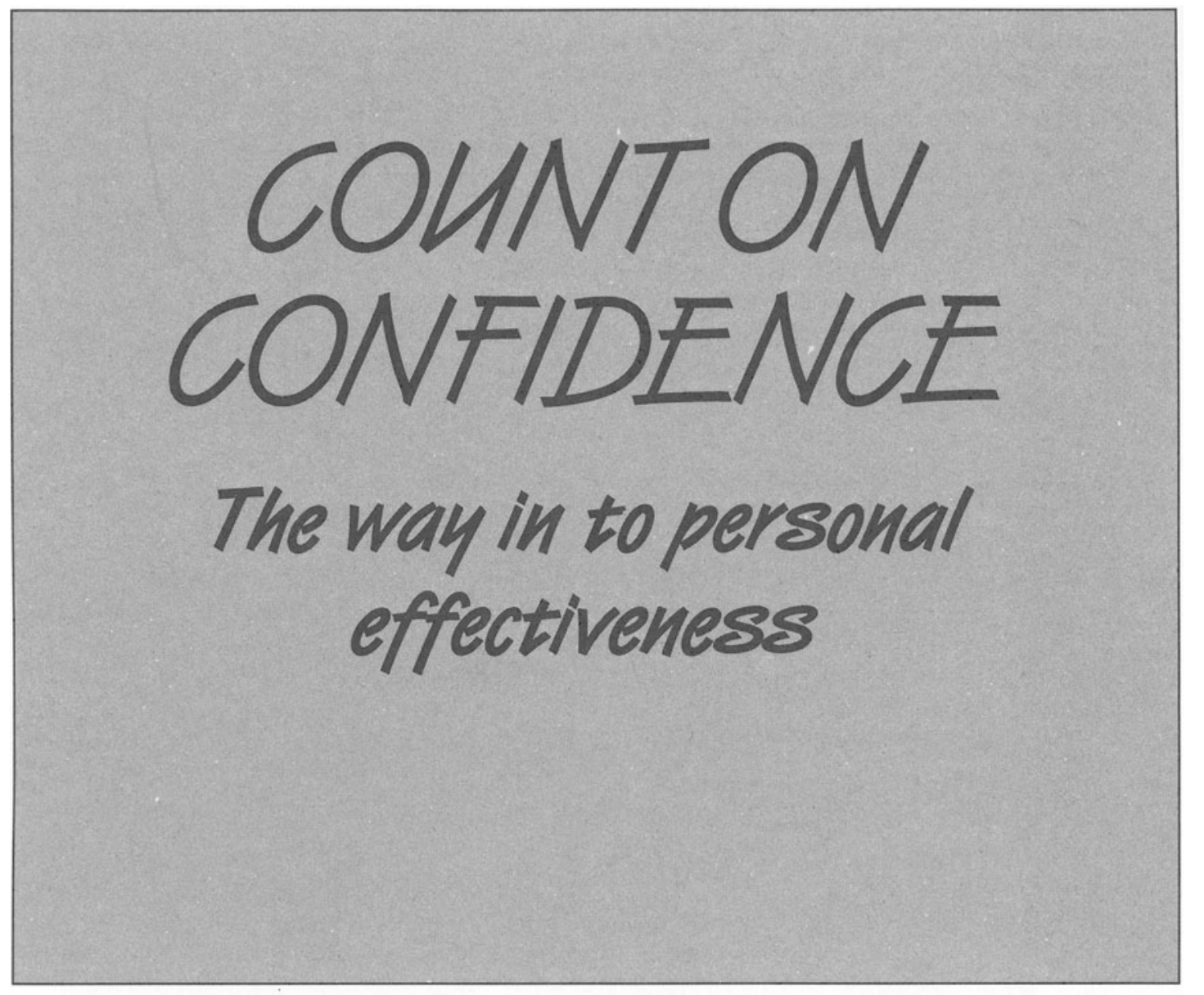

\section{Peggy Chisholm}

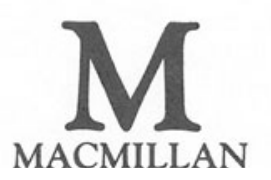




\section{(C) Peggy Chisholm 1990}

All rights reserved. No reproduction, copy or transmission of this publication may be made without written permission.

No paragraph of this publication may be reproduced, copied or transmitted save with written permission or in accordance with the provisions of the Copyright, Designs and Patents Act 1988, or under the terms of any licence permitting limited copying issued by the Copyright Licensing Agency, 33-4 Alfred Place, London WC1E TDP.

Any person who does any unauthorised act in relation to this publication may be liable to criminal prosecution and civil claims for damages.

First published 1990

Published by

MACMILLAN EDUCATION LTD

Houndmills, Basingstoke, Hampshire RG21 2XS

and London

Companies and representatives

throughout the world

British Library Cataloguing in Publication Data

Chisholm, Peggy

Count on confidence: the way in to

personal effectiveness

1. Personnel. Self-actualisation - Manuals

I. Title

658.3'14

ISBN 978-0-333-43811-4

DOI 10.1007/978-1-349-20630-8 


\section{Contents}

Acknowledgements

xvii

Introduction

xviii

1 Confidence 1

Aspects of confidence 1

Confidence versus intelligence 1

Discussion 1

Vulnerability 2

Self-damage $\quad 2$

The fragile asset $\quad 2$

The ill-prepared 3

The challenge 3

Discussion 4

Two-way process 4

Discussion 4

Discipline $\quad 4$

Discussion $\quad 5$

The propping-up process $\quad 5$

Discussion $\quad 5$

Creating confidence $\quad 5$

$\begin{array}{ll}\text { Self-awareness } & 6\end{array}$

The 'right' to happiness? $\quad 6$

Discussion 6

$\begin{array}{ll}\text { Self-doubt } & 7\end{array}$

Self-worth $\quad 8$

Fear $\quad 8$

$\begin{array}{ll}\text { Knowing ourselves better } & 9\end{array}$

Assignment 9

The interview 10

$\begin{array}{ll}\text { The application } & 10\end{array}$

Assignment 11

Right person/right job $\quad 11$

Say 'no' if you have to 11

Plan the route $\quad 11$ 
Face to face $\quad 12$

Helpful homework $\quad 12$

'On spec' 13

The hurdles $\quad 13$

Eye to eye 14

How you look 14

Two-way questions $\quad 14$

Pros and cons $\quad 15$

Positive leave-taking $\quad 15$

Summing-up 16

Promotion 17

Luck is not all 17

$\begin{array}{ll}\text { Watch-out } & 17\end{array}$

Discussion $\quad 18$

$\begin{array}{ll}\text { Twists and turns } & 18\end{array}$

Prepare for prospects $\quad 18$

$\begin{array}{ll}\text { Think ahead } & 19\end{array}$

Strike out $\quad 19$

Selling skills $\quad 19$

Personal best $\quad 19$

Individual stamp $\quad 20$

Opportunity knocked $\quad 20$

Discussion $\quad 21$

Getting to know YOU

Discussion $\quad 22$

2 People and work $\quad 23$

Taking the plunge $\quad 23$

Accent on attitudes $\quad 24$

How right is the customer? 24

Discussion $\quad 25$

Reaction to criticism $\quad 25$

Emotional cover-up $\quad 25$

Count it a plus $\quad 26$

Discussion $\quad 26$

Responsibility $\quad 26$

The commitment $\quad 26$

Find the errors $\quad 27$

Learn by mistakes $\quad 27$

At the ready $\quad 27$

Discussion 28

Lack of involvement $\quad 28$

Acceptable attitudes $\quad 28$

Discussion $\quad 28$ 
Decision-making $\quad 29$

$\begin{array}{ll}\text { Loyalty } & 29\end{array}$

Discussion $\quad 29$

Carrying the buck $\quad 30$

Continuous confidentiality $\quad 30$

Discussion $\quad 30$

Games people play $\quad 30$

Discussion $\quad 31$

Respect $\quad 31$

'Call me Jim ...' 31

First names $\quad 32$

Discussion $\quad 32$

Over-familiarity 33

Discussion $\quad 33$

A 'fair' deal $\quad 33$

The 'bully boys' 33

Discussion $\quad 34$

Anticipation $\quad 35$

The 'nitty gritty' $\quad 35$

Project $\quad 35$

Task $\quad 36$

Discussion 36

Communications $\quad 37$

Body language $\quad 37$

Listening $\quad 38$

Discussion $\quad 38$

$\begin{array}{ll}\text { End-of-chapter task } & 38\end{array}$

3 Verbal communication $\quad 39$

Voice value $\quad 39$

Defence mechanisms $\quad 39$

The all-important breathing $\quad 39$

Shock tactics? $\quad 40$

The agony of elocution $\quad 40$

Nervous differences $\quad 41$

Discussion $\quad 41$

The reluctant voice $\quad 41$

Discussion 43

'Power' of the voice 43

The revealing tone $\quad 43$

The 'soft sell'

Discussion $\quad 44$

Job hopping $\quad 44$

Discussion $\quad 45$ 
$\begin{array}{ll}\text { Telephone manner } & 46\end{array}$

The exasperated caller $\quad 46$

Company image $\quad 46$

Discussion $\quad 46$

The aggressive caller $\quad 46$

The cold-blooded answer-phone $\quad 47$

Money well-spent $\quad 47$

Even our best friends won't tell us $\quad 47$

Good example $\quad 49$

Who should say? 49

Discussion $\quad 50$

Accents and dialects $\quad 50$

No 'posh' accent $\quad 51$

No 'pseudo' replacement $\quad 51$

Discussion $\quad 51$

Voice project $\quad 52$

Forget conformity $\quad 52$

Discussion $\quad 52$

Verbal communication - voice development recommendations 53

4 Social and business behaviour $\quad 55$

Introductions $\quad 55$

Clear speaking $\quad 55$

How much to say? $\quad 55$

Discussion $\quad 56$

Use of titles $\quad 58$

Projects - social occasions $\quad 60$

$\begin{array}{ll}\text { Invitations } & 61\end{array}$

Issuing invitations $\quad 61$

$\begin{array}{ll}\text { Replying to invitations } & 67\end{array}$

Time of a function $\quad 68$

$\begin{array}{lr}\text { Parties } & 69\end{array}$

Coping with alcohol $\quad 69$

$\begin{array}{ll}\text { Discussion } & 70\end{array}$

$\begin{array}{ll}\text { Social mixing } & 71\end{array}$

$\begin{array}{ll}\text { Leave taking } & 71\end{array}$

$\begin{array}{ll}\text { Project } & 71\end{array}$

$\begin{array}{ll}\text { When to arrive } & 72\end{array}$

Discussion $\quad 73$

$\begin{array}{ll}\text { Hosting } & 73\end{array}$

$\begin{array}{ll}\text { Looking good - feeling good } & 73\end{array}$

$\begin{array}{ll}\text { How many guests to invite? } & 74\end{array}$

$\begin{array}{ll}\text { Food } & 74\end{array}$

Wine $\quad 74$

'Ingredients' rehearsal $\quad 75$ 
$\begin{array}{ll}\text { Time-savers } & 75\end{array}$

Bread variations $\quad 75$

Washing up $\quad 75$

Dinners and buffets $\quad 76$

Planning a dinner $\quad 76$

$\begin{array}{ll}\text { The programme } & 77\end{array}$

Buffets $\quad 77$

$\begin{array}{ll}\text { Flowers } & 78\end{array}$

Dinner table $\quad 78$

$\begin{array}{ll}\text { Discussion } & 79\end{array}$

$\begin{array}{ll}\text { Some do's } & 79\end{array}$

Projects I and II $\quad 79$

Restaurants and hotels $\quad 80$

$\begin{array}{ll}\text { Arrivals } & 80\end{array}$

Pre-dinner drinks $\quad 80$

The table and menu $\quad 81$

$\begin{array}{ll}\text { Cutlery } & 81\end{array}$

The wine list $\quad 82$

Handling bread $\quad 82$

Dessert and coffee $\quad 82$

The bill

Discussion $\quad 83$

Eating tricky dishes $\quad 83$

Discussion $\quad 85$

Restaurant dinner assignment $\quad 85$

Hotels $\quad 86$

Selection $\quad 86$

Learning by experience $\quad 86$

Discussion $\quad 88$

What to expect $\quad 88$

Assignment $\quad 89$

'Manners' today $\quad 89$

Discussion $\quad 90$

5 Personal presentation $\quad 91$

Women at work $\quad 91$

Discussion $\quad 91$

Professionalism - what is it? $\quad 92$

Discussion $\quad 92$

The effect of professionalism $\quad 92$

No added stress $\quad 92$

Society versus the real you $\quad 93$

Bridging the gap $\quad 94$

The shyness problem $\quad 94$

Discussion $\quad 94$ 
A 'together' look 95

Creating impressions $\quad 96$

Choice of clothes $\quad 96$

Clothes wardrobe - men $\quad 96$

$\begin{array}{ll}\text { The suit } & 96\end{array}$

$\begin{array}{ll}\text { To go with the suit } & 97\end{array}$

$\begin{array}{ll}\text { Casual wear } & 98\end{array}$

$\begin{array}{ll}\text { Evening wear } & 98\end{array}$

'Labels' (men) 98

Clothes wardrobe - women $\quad 99$

A suit $\quad 99$

Good basics $\quad 99$

Casual wear $\quad 99$

$\begin{array}{ll}\text { Shoes } & 100\end{array}$

$\begin{array}{ll}\text { Evening wear } & 100\end{array}$

$\begin{array}{ll}\text { Discussion } & 100\end{array}$

$\begin{array}{ll}\text { Project } & 100\end{array}$

'Labels' (women) 101

What suits YOU? 101

Heat-wave dressing $\quad 101$

$\begin{array}{lr}\text { Affordability } & 102\end{array}$

$\begin{array}{ll}\text { Discussion } & 102\end{array}$

$\begin{array}{ll}\text { Bargain hunters } & 103\end{array}$

'Ideal' wardrobe $\quad 103$

$\begin{array}{ll}\text { Discussion } & 103\end{array}$

$\begin{array}{lr}\text { Style } & 104\end{array}$

Clues to look for $\quad 104$

Window on the fashion industry 105

'Collections'

105

Publications $\quad 106$

Alternative 'scanning' tasks $\quad 106$

Discussion $\quad 106$

$\begin{array}{ll}\text { Assignment } & 106\end{array}$

$\begin{array}{lr}\text { Shoes } & 107\end{array}$

Damage to body and sole $\quad 107$

$\begin{array}{ll}\text { Look good - feel awful } & 107\end{array}$

$\begin{array}{ll}\text { Take care of your investment } & 108\end{array}$

$\begin{array}{ll}\text { Discussion } & 108\end{array}$

$\begin{array}{lr}\text { Jewellery } & 108\end{array}$

Discussion $\quad 108$

'Real' fakes 109

Not necessarily 'pricey' 109

'Jangling' to work 109

Project 
Dress for succes $\quad 110$

Finding your OWN image $\quad 110$

$\begin{array}{ll}\text { Discussion } & 110\end{array}$

6 Skin care and make-up $\quad 111$

Skin care $\quad 111$

No easy way $\quad 111$

The face $\quad 111$

Dry skin $\quad 112$

Oily skin $\quad 112$

Combination skin $\quad 112$

Problem skin $\quad 112$

Cleanse before anything 113

Basic cleansing routine $\quad 113$

Products 114

Skin Fresheners/toners $\quad 114$

Precious moisture $\quad 115$

$\begin{array}{ll}\text { Skin rubs } & 115\end{array}$

Face packs $\quad 116$

For the men $\quad 117$

Black skins (men) $\quad 117$

$\begin{array}{ll}\text { Shaving } & 117\end{array}$

Skin care summary $\quad 117$

$\begin{array}{ll}\text { Project } & 118\end{array}$

$\begin{array}{ll}\text { Make-up } & 118\end{array}$

Best face forward $\quad 119$

$\begin{array}{ll}\text { Tips galore } & 120\end{array}$

Discussion $\quad 122$

Black skins (women) 122

Make-up 'influence' 123

Make-up manipulation $\quad 123$

$\begin{array}{ll}\text { Discussion } & 124\end{array}$

$\begin{array}{ll}\text { Practicalities } & 124\end{array}$

Collecting basic equipment $\quad 124$

Applied techniques $\quad 125$

Eye-brow shape $\quad 125$

How to apply foundation $\quad 125$

$\begin{array}{ll}\text { Concealer } & 125\end{array}$

Face powder $\quad 126$

Blusher $\quad 126$

Eye make-up $\quad 126$

$\begin{array}{ll}\text { Highlighter } & 127\end{array}$

Mascaras $\quad 127$

$\begin{array}{ll}\text { Lips } & 127\end{array}$ 
$\begin{array}{ll}\text { Suggested project }- \text { make-up session } & 128\end{array}$

Perfume

Selection time

Discussion

Half-way assessment

7 Health

The healthy look

Risky eating

135

Dynamic dieters

135

The work scene

Strike a balance

136

Practical life-style eating

137

Basic rules

A balanced day

Food/drinks to avoid

What and when to drink

Planning the meals

Will-power

Make a start

Budget eating

Discussion

Do's and don'ts

Listen to your body

The quiet diet

No foolish fads

Holistic medicine

The WHOLE person

Controversy

Check it out

Possible 'marriage'

Holistic practices

Acupuncture

Chiropractic and osteopathy

Herbalism

Homoeopathy

Aromatherapy

Reflexology

Discussion

Mind over matter

Discussion

The entrepreneur 
Project

Follow up: added discussion points

Discussion

Experimenters

Priority of knowledge

No special place in society

152

Cigarettes

The delusive puff

Discussion

Alcohol

Social acceptance

154

The alcohol ' $\mathrm{mix}^{\prime}$

154

Who cares?

Discussion

Project

Just say 'no'

Other drugs

Tranquillisers

Barbiturates

Caffeine

Solvents

What to do in an emergency?

Recreation or desperation

Discussion

8 Body care

The bath

Treat yourself

Perspiration

Massage

Up-tight

A different cleanser

Skin in the sun

Easy does it

Clue-in to precautions

Black skin in the sun

The killer sun

Discussion

Nails

Health check 
Rescue tactics $\quad 164$

Water wary $\quad 164$

Short on nutrients? $\quad 165$

The manicure $\quad 165$

Step by step $\quad 165$

Down to the quick $\quad 166$

Practical hints 166

Men included 166

Discussion $\quad 166$

Hands $\quad 167$

Hints $\quad 167$

$\begin{array}{ll}\text { Discussion } & 167\end{array}$

$\begin{array}{ll}\text { Feet } & 167\end{array}$

Dead give-away 168

$\begin{array}{ll}\text { Treatment } & 168\end{array}$

Teeth 168

Villain of the piece $\quad 168$

Cleaning of the teeth 169

Effective technique 169

$\begin{array}{ll}\text { Other aids } & 169\end{array}$

Hair (wanted) 169

Crowning glory $\quad 170$

$\begin{array}{ll}\text { Washing } & 170\end{array}$

Drying 170

Blow-dry method 171

Easy on the heat $\quad 171$

Cutting 172

Follow the cutter $\quad 172$

On the cheap 172

Make a plan $\quad 172$

$\begin{array}{ll}\text { The tip } & 173\end{array}$

Colour 173

$\begin{array}{ll}\text { Conditioners } & 173\end{array}$

Perms $\quad 173$

Care with chemicals $\quad 173$

$\begin{array}{ll}\text { Dandruff } & 174\end{array}$

Hair (men) $\quad 174$

Straightforward control for most male hair $\quad 174$

Afro hair $\quad 174$

Discussion $\quad 174$

Hair (unwanted) 175

Body hair removal $\quad 175$

$\begin{array}{ll}\text { No let-up } & 177\end{array}$ 
9 Stretch your body $\quad 178$

$\begin{array}{ll}\text { Stress } & 178\end{array}$

$\begin{array}{ll}\text { The art of relaxation } & 179\end{array}$

Designed for action $\quad 180$

'Hooked' on it $\quad 181$

$\begin{array}{ll}\text { Stretching for fitness } & 181\end{array}$

Discussion $\quad 181$

The supple look $\quad 181$

Method 182

Better breathing $\quad 182$

Pre-stretch routine $\quad 182$

Basic starting positions $\quad 183$

'Relax' position $\quad 184$

$\begin{array}{ll}\text { Warm up } & 184\end{array}$

Neck movements $\quad 185$

Neck and shoulders $\quad 186$

Arms, sides and legs $\quad 187$

Buttocks and thighs 188

$\begin{array}{ll}\text { Floor exercises } & 188\end{array}$

$\begin{array}{ll}\text { Spine preparation } & 188\end{array}$

Upper stomach $\quad 189$

Stomach, waist, buttocks, hips and thighs $\quad 189$

Outer thighs, stomach and buttocks 191

Male flabby stomach - plus back and shoulders 191

Cellulite thighs

All-over shaper

192

Legs and thighs 194

$\begin{array}{ll}\text { Thighs } & 195\end{array}$

Self-defence $\quad 196$

Discussion $\quad 197$

Deportment $\quad 197$

Discussion 198

Alexander technique $\quad 198$

Fitness confidence 199

10 Stretch your mind $\quad 199$

Natural curiosity 199

Observation 199

Discussion 199

Awareness 199

Discussion $\quad 200$

Exploration 200

$\begin{array}{ll}\text { The whole person } & 200\end{array}$ 
The open mind $\quad 201$

Discussion $\quad 201$

'Holding on' $\quad 202$

Discussion $\quad 202$

Widening horizons $\quad 202$

Discussion $\quad 202$

The world around us 203

Discussion $\quad 203$

Early attitudes $\quad 203$

Quest for knowledge $\quad 204$

The manageable memory $\quad 204$

Forgetting to remember $\quad 205$

The practical approach $\quad 205$

Brilliance not obligatory $\quad 205$

Discussion 206

Expectations 206

Discussion $\quad 206$

Bewitched and brainwashed 206

Discussion $\quad 207$

Expectations gone wrong $\quad 207$

The eternal triangle $\quad 207$

Discussion $\quad 208$

'Go for it' 208

Project 208

Opportunities ahead $\quad 208$

Work 'stretching' assignments $\quad 209$

Personnel priorities $\quad 210$

$\begin{array}{ll}\text { Project } & 210\end{array}$

Money, money, money . . .

Discussion $\quad 211$

$\begin{array}{ll}\text { Project } & 212\end{array}$

Keep on asking $\quad 212$

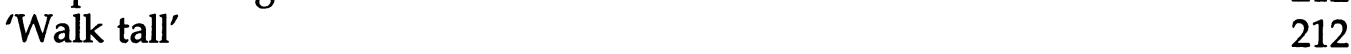




\section{Acknowledgements}

I wish to express my gratitude to all who have helped me with this book and especially to the following:

Cicely Berry, not only for her expertise in Voice but for her real understanding of human values.

Dr Vernon Coleman for his simplified, straightforward approach to a better understanding of the mind and body.

Helen and Ron Clarke of Cannons Sports Club (UK) Ltd for checking out my movement exercises with such interest and thoroughness.

Doris Grant and Jean Joice for revising the Hay System and making available such a healthy way of eating.

Alan Didymus, Police Schools Liaison Officer, who took time out to explain his relevant and interesting role in the present education system.

Sigrud Engelen of the Bath Area Drugs Advisory Service for her interest and help and for giving me much of her valuable time.

My editor, John Winckler, for the help (and push!) afforded to me, and to Christine Simons who twisted my arm in the first place.

The author and publishers wish to thank the following who have kindly given permission for the use of copyright material.

Vernon Coleman for an extract from Bodypower, Thames \& Hudson.

Every effort has been made to trace all the copyright holders but if any have been inadvertently overlooked the publishers will be pleased to make the necessary arrangement at the first opportunity. 


\section{Introduction}

"What does success mean to you?"

Quite a question, and the more you think about it the more difficulty you will have in finding an answer. Peggy Chisholm puts the question in one of the last projects of her valuable book, Count on Confidence, a book in which she uses her extensive knowledge and experience to help you find an answer to this fundamental question.

Nothing succeeds like success, and success breeds confidence. That same confidence - not over-confidence - is itself an important ingredient of success. There are many more. The knowledge and skills you bring to a job and the drive and energy you put into it will be important contributors to your success at work. Your ability to get on well with other people will be important. And luck, that handmaiden of success, will play its part.

Self-confidence will support you in the workplace. You will demonstrate the skill and knowledge you can contribute without feeling shy, you will be able to get on with a job without supervision and not feel afraid. You will be able to deal effectively with those working with you whatever their level of seniority, whatever their social background.

Confidence in yourself will help you make the most of the qualities with which you are endowed. In many ways you resemble a shopkeeper with goods to sell. These may be of the finest quality but if they are kept at the back of the shop where nobody can see them, business will be poor. Sales will improve when the goods are displayed in the shop window, attractively and enticingly displayed not simply pushed in with no thought or effort. The shopkeeper will feel confident when he has made a good job of dressing his window. His sales will improve and that in turn will help his confidence.

But beware! In the long run, however well the window is dressed the business will not thrive if the goods are of poor quality. Peggy Chisholm's excellent book shows you how to make the most of yourself, how to dress your personal shop window and to be a success. But if you are lazy and incompetent, success will avoid you however good you look and however confident you are in your own abilities.

A quick glance at this book's contents will show you the wide variety of topics dealt with. Assisted by discussion and assignment tasks and frequent project work, you will learn how to care for your personal appearance, to communicate well and how to behave in different situations. You will have the knowledge and experience of a learned author to guide and help you increase your effectiveness not only at work but outside the working environment in your private life.

Life is a challenge. This book will help you meet that challenge with confidence. 